\title{
Ultrasonographic Measurement of the Thyroid Isthmus Thickness in Healthy Turkish Infants, Children, and Adolescents
}

\author{
Sağlıklı Türk İnfant, Çocukluk ve Adolesan Yaş Grubunda Tiroid İstmus Kalınlığının \\ Ultrasonografik Ölçümü
}

\author{
(Ddis Çolak', Behzat Özkan², Burak Polat ${ }^{1}$, @Sinan Genç ${ }^{3}$ \\ 'University of Health Sciences Dr. Behçet Uz Child Disease and Pediatric Surgery Training and Research Hospital, Department of Radiology, Izmir, \\ Turkey \\ ${ }^{2}$ University of Health Sciences Dr. Behçet Uz Child Disease and Pediatric Surgery Training and Research Hospital, Department of Pediatric \\ Endocrinology and Metabolism, Izmir, Turkey \\ ${ }^{3}$ University of Health Sciences Dr. Behçet Uz Child Disease and Pediatric Surgery Training and Research Hospital, Department of Pediatric \\ Radiology, Izmir, Turkey
}

\section{ABSTRACT}

Aim: The importance of establishing reference ranges for thyroid volume is a worldwide trend, however, to date, limited data are available regarding thyroid isthmus thickness (TIT) in healthy children. The present study aimed to report the reference values for TIT in children aged between 0 and 18 years from Turkey.

Material and Method: The TIT was measured by ultrasonography in 447 subjects between December 2018 and September 2020. The 3rd, 10th, 25th, 50th, 75th, and 95th percentiles of the TIT according to age and gender were determined and compared with published data. The TIT values were compared with children's age, gender, and Z-score data for weight, height, and body mass index (BMI).

Results: The median [interquartile range (IQR) 25 - 75] values for TIT were $1.5(1.3-2.0) \mathrm{mm}$. The TI was thicker in females than in males and this gender difference was statistically significant ( $1.6 \mathrm{~mm}$ vs. $1.5 \mathrm{~mm}, \mathrm{p}=0.023$, respectively). The TIT was highly significantly associated with age, and Z-scores for weight, height, and BMI ( $r=0.461, r=0.457, r=0.448$, and $r=0.434$, respectively; $p<0.0001$ for all). Z-score for weight was the strongest predictor of the TIT in the multivariate regression model.

Conclusion: This study is the first to report the normative data for TIT in healthy Turkish infants, children, and adolescents. The present results will provide valuable scientific input for developing reference standards for TIT on a national and international level.

Keywords: Thyroid isthmus, thyroid isthmus thickness, ultrasound

\section{ÖZ}

Amaç: Tiroit bez hacmi için referans aralıklarının oluşturulması dünya çapında bir trend olmasına rağmen bugüne kadar sağlıklı çocuklarda tiroit istmus kalınlığı (TiK) ile ilgili sınırlı veri mevcuttur. Bu çalışmanın amacı 0-18 yaş arası Türk çocuklarda TiK'nın referans değerlerini belirlemektir.

Gereç ve Yöntem: Aralık 2018 - Eylül 2020 tarihleri arasında 447 kişide TiK ultrasonografi ile ölçüldü. TiK için 3., 10., 25., 50., 75. ve 95. persentil değerleri yaş ve cinsiyete göre hesaplandı ve yayınlanan verilerle karşılaştırıldı. Tỉ değerleri, çocukların yaş, cinsiyet ve ağırlık, boy, vücut kitle indeksi (VKi) Z-skorları ile karşılaştırıldı.

Bulgular: TiK medyan [çeyrekler arası aralık (IQR) 25 - 75] değerleri 1,5 (1,3-2,0) mm idi. Tiroit istmus kadınlarda erkeklere göre daha kalındı ve bu cinsiyet farkı istatistiksel açıdan anlamlıydı (sırasıyla 1.,6 mm, 1,5 mm ve $p=0,023)$. Tik ve yaş, ağırlık, boy, VKi Z-skor değerleri arasında belirgin fark gözlendi (sırasıyla $r=0,461, r=0,457$, $r=0,448$ ve $r=0,434 ; p<0,0001)$. Ağırlık Z-skoru, çok değişkenli regresyon modelinde, TiK'nın en güçlü belirleyicisiydi.

Sonuç: Bu çalışma, sağlıklı Türk infant, çocukluk ve adolesan yaş grubunda Tik'nın normatif verileri bildiren ilk çalışmadır. Mevcut sonuçlar, ulusal ve uluslararası düzeyde Tik referans standartlarının geliştirilmesi için önemli bilimsel katkı sağlayacaktır.

Anahtar Kelimeler: Tiroit istmus, tiroit istmus kalınlığı, ultrason

Corresponding Author: Edis Çolak

Address: Department of Radiology, University of Health Sciences Dr. Behçet Uz Child Disease and Pediatric Surgery Training and Research Hospital, Izmir, Turkey

E-mail: edisezgicolak@gmail.com 


\section{INTRODUCTION}

The thyroid isthmus (TI) is a bridge of tissue that connects the two thyroid lobes and is predisposed to the same congenital and acquired disorders as the rest of the thyroid gland (1-3). In iodine-deficient regions, goiter is the most common cause of thyroid gland and $\mathrm{TI}$ enlargement in children. The thyroid isthmus thickness (TIT) may also increase in children with Hashimoto thyroiditis, Graves' disease, and acute infectious thyroiditis. The absence of the TI may be due to TI agenesis, post-radioactive iodine ablation of the thyroid gland, or total thyroidectomy. Moreover, thyroid nodules located in the TI are at higher risk of malignant transformation than those found in the thyroid lobes (3). The TIT is not included in the ultrasonographic (US) measurement of the thyroid volume. Therefore, the TIT should be measured and noted as a part of each thyroid US examination as recommended by Kosiak et al. (4).

The importance of providing reference data for thyroid volume is a worldwide trend, however, it is striking that limited data are available for TIT. To the best of our knowledge, no previous study has reported the normal values for the TIT among Turkish children from different age groups. The objective of the present study was to establish the reference data for TIT in healthy children aged between 0 and 18 years from Turkey.

\section{MATERIAL AND METHOD}

The study protocol was performed in compliance with the Declaration of Helsinki and approved by the Ethics Committee of our University Hospital (protocol number: 2020-458). All procedures were carried out in accordance with the ethical rules and the principles of the Declaration of Helsinki.

We reviewed the radiology reports of the 498 subjects who underwent thyroid US examinations between December 2018 and September 2020. The exclusion criteria were age $>18$ years old; heterogeneous echogenicity of the thyroid gland $[n=32]$; nodule located in the $\mathrm{TI}[\mathrm{n}=7]$; thyroidectomy $[\mathrm{n}=5]$; a pyramidal lobe originated from the midline of the $\mathrm{TI}[\mathrm{n}=1](5,6)$; and abnormal thyroid function (T3, T4, and TSH) $[n=6]$. A total of 447 patients with normal thyroid function (T3, T4, and TSH) tests were finally included for analysis.

ThyroidUSmeasurementswereobtained byoneradiologist certified by the European Board of Radiology with 5 years of experience. A diagnostic US system (Aplio 500; Toshiba Medical Systems Corporation, Otawara, Japan) with a 5-12 MHz linear transducer was used. Participants were studied in the supine position. On a transverse image, the maximum anteroposterior diameter of the $\mathrm{TI}$ was measured at its thickest part at the midline (Figure 1). Data on demographic characteristics including age, gender, weight, and height were collected from the medical records. The Z-scores for weight, height, and BMI were derived from the reference data for Turkish children (7).

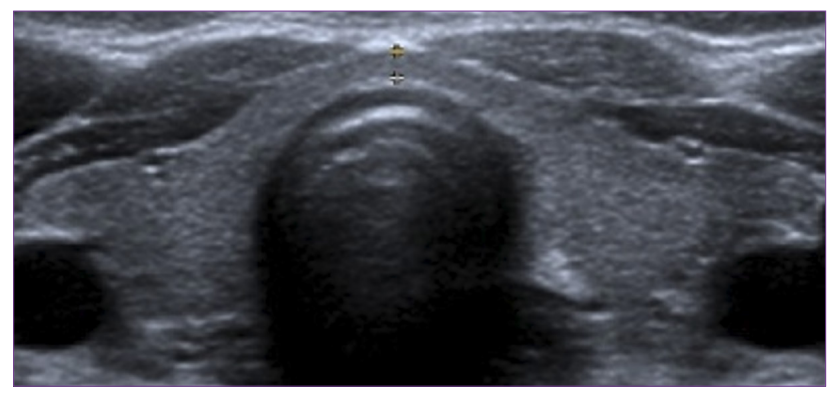

Figure 1. The maximum thickness of the thyroid isthmus is shown on a transverse ultrasound image of the thyroid gland in a 7-year-old male patient.

Numeric variables were reported as median (interquartile range [IQR]), as the data proved to be skewed distributed when analyzed by the SkewnessKurtosis test and Kolmogorov-Smirnov test. The results were carried out using the Chi-square test and the Kruskal-Wallice test. Significant correlations were calculated by Spearman's rank correlation test. After the logarithmic transformation of not normally distributed variables, stepwise multivariable regression analysis was performed to assess the independent predictors of the TIT. The SPSS software version 20.0 (SPSS Inc., Chicago, IL, USA) was used for statistical analyses. P values of less than 0.05 and less than 0.001 were regarded as significant and highly significant.

\section{RESULTS}

The total study group included 273 (61.6\%) girls and 174 (38.9\%) boys. The mean \pm SD age of the subjects was 10.88 \pm 4.79 (range 0-18) years. Children were stratified into seven groups according to their age. The age groups were selected according to the criteria suggested by the Medical Subject Headings (infants, toddlers, preschoolers, primary school-aged children, secondary school-aged children, and adolescents). The median [interquartile range (IQR) 25 - 75] Z scores for weight, height, and BMI were $-0.25(-0.94-0.91) \mathrm{kg}, 0.39(-0.74-$ $0.78) \mathrm{m}$, and $-0.12(-0.92-0.87) \mathrm{kg} / \mathrm{m}^{2}$, respectively.

The median (IQR) values for TIT were $1.5(1.3-2.0) \mathrm{mm}$. The TI was thicker in females (median: 1.6; IQR: 1.4-2.1) compared to males (median: 1.5; IQR: 1.3-2.0) and this gender difference was statistically significant $(p=0.023)$. The age of the children was positively associated with the TIT $(r=0.461, p<0.001)$. Data for TIT stratified by age and gender are demonstrated in Table 1. The 3rd, 50th, and 95th percentiles of the TIT according to age and gender are depicted in Figure 2. 


\begin{tabular}{|c|c|c|c|c|c|c|c|c|}
\hline \multirow{2}{*}{ Age } & \multirow{2}{*}{$\begin{array}{l}\text { Gender } \\
\text { (n) }\end{array}$} & \multicolumn{6}{|c|}{ Thyroid Isthmus Thickness (mm) } & \multirow{2}{*}{$\begin{array}{c}\mathbf{p} \\
\text { values }\end{array}$} \\
\hline & & P3 & P10 & P25 & P50 & P75 & P95 & \\
\hline \multirow{3}{*}{$\begin{array}{l}0-12 \\
\text { months }\end{array}$} & $M(11)$ & 0.70 & 0.70 & 1.00 & 1.30 & 1.70 & 2.46 & \multirow{3}{*}{0.356} \\
\hline & $F(6)$ & 1.00 & 1.00 & 1.00 & 1.50 & 1.63 & 1.95 & \\
\hline & $\mathrm{T}(17)$ & 0.70 & 0.70 & 1.00 & 1.50 & 1.60 & 2.21 & \\
\hline \multirow{3}{*}{$\begin{array}{l}1-4 \\
\text { years }\end{array}$} & M (18) & 0.80 & 0.80 & 1.00 & 1.35 & 1.60 & 2.03 & \multirow{3}{*}{0.516} \\
\hline & $\mathrm{F}(21)$ & 0.80 & 1.02 & 1.20 & 1.50 & 1.70 & 2.46 & \\
\hline & T (39) & 0.80 & 1.00 & 1.10 & 1.50 & 1.60 & 2.20 & \\
\hline \multirow{3}{*}{$\begin{array}{l}5-7 \\
\text { years }\end{array}$} & M (29) & 0.50 & 0.90 & 1.05 & 1.50 & 1.60 & 2.25 & \multirow{3}{*}{0.350} \\
\hline & $F(33)$ & 1.00 & 1.00 & 1.10 & 1.50 & 1.50 & 2.15 & \\
\hline & $\mathrm{T}(62)$ & 0.68 & 1.00 & 1.08 & 1.50 & 1.50 & 2.17 & \\
\hline \multirow{3}{*}{$\begin{array}{l}8-10 \\
\text { years }\end{array}$} & M (30) & 1.00 & 1.00 & 1.20 & 1.50 & 1.63 & 2.32 & \multirow{3}{*}{0.066} \\
\hline & $F(44)$ & 1.00 & 1.00 & 1.10 & 1.40 & 2.00 & 3.25 & \\
\hline & $\mathrm{T}(74)$ & 1.00 & 1.00 & 1.10 & 1.50 & 2.00 & 2.55 & \\
\hline \multirow{3}{*}{$\begin{array}{l}11-13 \\
\text { years }\end{array}$} & M (38) & 1.00 & 1.00 & 1.40 & 1.50 & 1.85 & 2.22 & \multirow{3}{*}{0.408} \\
\hline & $F(52)$ & 0.80 & 1.06 & 1.50 & 1.60 & 2.10 & 3.20 & \\
\hline & $\mathrm{T}(90)$ & 0.95 & 1.00 & 1.40 & 1.50 & 2.00 & 3.00 & \\
\hline \multirow{3}{*}{$\begin{array}{l}14-16 \\
\text { years }\end{array}$} & M (34) & 1.01 & 1.30 & 1.50 & 1.90 & 2.00 & 3.05 & \multirow{3}{*}{0.513} \\
\hline & $F(80)$ & 1.09 & 1.32 & 1.50 & 2.00 & 2.50 & 3.20 & \\
\hline & $\mathrm{T}(114)$ & 1.09 & 1.30 & 1.50 & 2.00 & 2.35 & 3.13 & \\
\hline \multirow{3}{*}{$\begin{array}{l}17-18 \\
\text { years }\end{array}$} & M (14) & 1.50 & 1.55 & 2.00 & 2.10 & 3.00 & 4.00 & \multirow{3}{*}{0.631} \\
\hline & $F(37)$ & 1.04 & 1.50 & 1.60 & 2.00 & 2.50 & 3.20 & \\
\hline & $\mathrm{T}(51)$ & 1.17 & 1.50 & 1.60 & 2.00 & 2.50 & 5.00 & \\
\hline \multirow{3}{*}{$\begin{array}{l}0-18 \\
\text { years }\end{array}$} & M (174) & 0.80 & 1.00 & 1.30 & 1.50 & 2.00 & 2.50 & \multirow{3}{*}{0.023} \\
\hline & $F(273)$ & 1.00 & 1.00 & 1.40 & 1.60 & 2.10 & 3.03 & \\
\hline & $\mathrm{T}(447)$ & 1.00 & 1.00 & 1.30 & 1.50 & 2.00 & 3.00 & \\
\hline
\end{tabular}

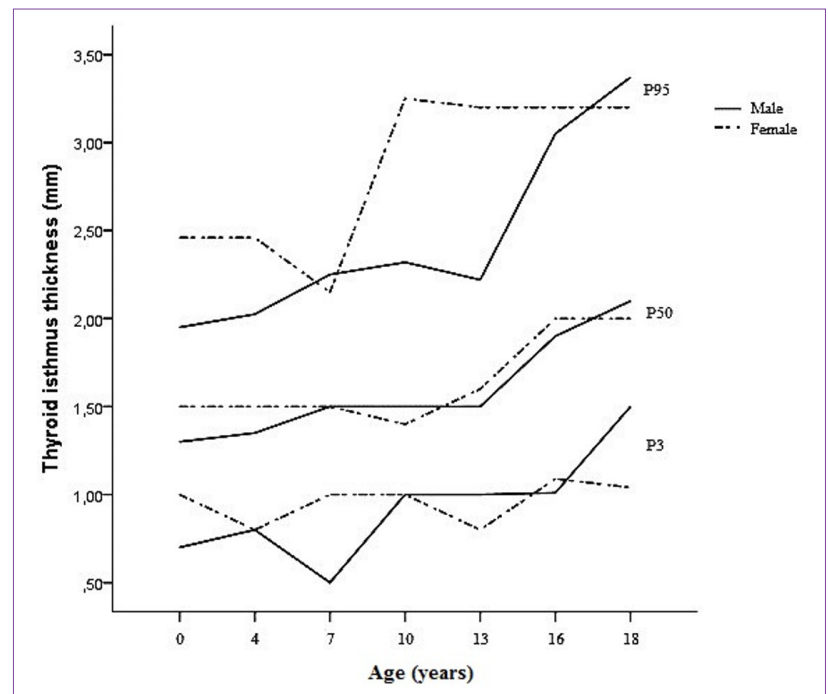

Figure 2. The graph presents the $3 \mathrm{rd}, 50 \mathrm{th}$, and 95 th percentiles of the age-dependent distribution of the thyroid isthmus thickness measured by ultrasonography among boys and girls.

The TIT was highly significantly associated with Z-scores for weight, height, and BMI ( $r=0.457, r=0.448$, and $r=0.434$, respectively; $p<0.0001$ for all). Z-score for weight was the only strongest predictor of the TIT in the multivariate regression model $[F(1,445)=99.007$, $\mathrm{p}<0.0001, \mathrm{R} 2=0.182]$.

\section{DISCUSSION}

The ultrasonographic measurement of the TIT may provide important diagnostic clues in pediatric patients with thyroid disorders $(1,4)$. Thyroid parenchymal diseases such as goiter, acute infectious thyroiditis, and autoimmune thyroiditis may manifest with diffuse $\mathrm{TI}$ enlargement $(1,3,8)$. A focal TI enlargement may be caused by thyroid nodules located in the TI. A reduction of the TIT and thyroid volume is observed in the end stage of Hashimoto's thyroiditis and radiation-induced thyroiditis (3). An absence of the TI in its anatomical location is detected in $\mathrm{Tl}$ agenesis, thyroid gland ectopia, and after thyroid gland surgery (3). The TIT is not included in the US estimation of the thyroid volume. Thus, it is recommended that TIT should be monitored as a part of each thyroid US examination (4). The proper diagnosis of children with thyroid disorders is highly dependent on the presence of relevant normative data for thyroid volume (9-11). However, only limited data are currently available in the literature for TIT.

The present study provides the first reference ranges for TIT measured by US in 447 healthy children and adolescents aged up to 18 years from Turkey. To date, reference values for TIT have been based on studies with limited sample sizes. To our knowledge, only Kosiak et al. have measured the TIT by US in 402 healthy prepubertal children (4). The median TIT for children aged 7 to 9 years was $1.9 \pm 0.74 \mathrm{~mm}$ for boys and $2.0 \pm 0.72 \mathrm{~mm}$ for girls. The recommended values for median TIT in 10-12-y-old boys and girls were $2.3 \pm 0.96 \mathrm{~mm}$ and $2.4 \pm 1.08 \mathrm{~mm}$, respectively. They have also proposed the upper cut-off values of $2.6 \mathrm{~mm}$ for boys and $2.7 \mathrm{~mm}$ for girls aged 7 to 9 years; $3.3 \mathrm{~mm}$ for boys and $3.5 \mathrm{~mm}$ for girls aged 10 to 12 years. The reported median values for TIT in children aged 7 to 12 years by Kosiak et al. in 2010 were $29.2 \%$ higher than the values reported in the present study. Our upper cut-off values for TIT among children of the same age range were $9.3 \%$ lower compared to those proposed by Kosiak et al. (4). These results are probably due to the successful implementation of the recommendations for iodine supplementation.

Recently, Kayastha et al. have evaluated the TIT in 485 individuals aged 1 to 83 years (12). The mean TIT was $3.1 \pm 0.9 \mathrm{~mm}$ for males, and $3.1 \pm 1.1 \mathrm{~mm}$ for females. In a study proposed by Şeker et al., the mean values for TIT in males and females among 251 adult patients from Turkey were $3.42 \pm 1.14$ and $3.10 \pm 1.05$, respectively (13). However, the age range in this work was 15-78 years and cannot be regarded as competent for pediatric patients. Won et al. reported that TIT was $3.6 \pm 1.9 \mathrm{~mm}$ in male and $3.1 \pm 1.4 \mathrm{~mm}$ in female adult cadavers (14). In another study carried out by Sultana et al. the mean values of the TIT in $<18$ years, $19-45$ years, and $>45$ years old cadavers were $4.45 \pm 1.36 \mathrm{~mm}, 4.72 \pm 2.68 \mathrm{~mm}$, and $4.91 \pm 1.78 \mathrm{~mm}$, respectively (15). In the present study, the median (IQR) 
values for the TIT were 1.5 (1.3-2.0) $\mathrm{mm}$ for boys, 1.6 (1.4-2.1) $\mathrm{mm}$ for girls, and 1.5 (1.3-2.0) $\mathrm{mm}$ for the total study population aged up to 18 years old. The higher values of the TIT in the $<18$ age group reported by Won et al. (14) might be explained by the differences in the diagnostic tools, year of research, age subgroups, racial, and geographical factors.

In the study by Kosiak et al., the TI was thicker among females (4). According to Kayatsa et al. and Şeker et al., the TI was thicker among males $(12,13)$. In the present study, the TI was thicker among girls and this gender difference was statistically significant. The gender difference could be explained by the fact that prepubertal girls are more susceptible to the effects of iodine insufficiency $(4,10,12)$. The TIT was highly significantly correlated with age, and Z-score data for weight, height, and BMI. Similar results were obtained in previous studies as well $(12,13)$.

An important strength of our study was its potential to fill a gap in the knowledge of the reference data for pediatric TIT in Turkey. However, some limitations need to be considered when interpreting the results of this study. Our work was a single-center study with a relatively small number of subjects in each age group, especially in the youngest age group $(n=17)$. Since all the TIT measurements were performed by a single radiologist, inter-observer variability should be taken into account in future studies. There was a lack of studies and consensus regarding normative data for TIT in children, thus, future multicenter studies with a larger sample size in each age group are required to confirm and generalize the results of the present work.

\section{CONCLUSION}

This is the first study to establish the data for TIT in healthy Turkish children. The present results will provide valuable scientific input for developing reference standards for TIT and we believe the results of this study might be used internationally for children from the newborn period up to 18 years of age.

\section{ETHICAL DECLARATIONS}

Ethics Committee Approval: The study protocol was performed in compliance with the Declaration of Helsinki and approved by the Ethics Committee of the University of Health Sciences Dr. Behçet Uz Child Disease and Pediatric Surgery Training and Research Hospital (protocol number: 2020-458).

Informed Consent: Because the study was designed retrospectively, no written informed consent form was obtained from patients.

Referee Evaluation Process: Externally peer-reviewed.
Conflict of Interest Statement: The authors have no conflicts of interest to declare.

Financial Disclosure: The authors declared that this study has received no financial support.

Author Contributions: All of the authors declare that they have all participated in the design, execution, and analysis of the paper, and that they have approved the final version.

\section{REFERENCES}

1. Babcock DS. Thyroid disease in the pediatric patient: emphasizing imaging with sonography. Pediatr Radiol 2006;36:299-308.

2. Nilsson $M$, Fagman $H$. Development of the thyroid gland. Development. 2017;15:2123-40.

3. Alexander LF, Patel NJ, Caserta MP, Robbin ML. Thyroid Ultrasound: Diffuse and Nodular Disease. Radiol Clin North Am. 2020;58:1041-54.

4. Kosiak W, Swięton D, Piskunowicz M, Kujawa M. Thyroid isthmus thickness in prepubertal healthy children in an iodine-sufficient region. Pol J Radiol 2010;75:17-9.

5. Çolak E. Ultrasonographic Evaluation of the Pyramidal Lobe of the Thyroid Gland in Infants and Children in Western Turkey Between 2018 and 2020, Iran J Radiol. 2021;18: e108543

6. Ramo Akgün N, (2021). Assistive Technology for Children with Intellectual Disabilities. In İscan, A., Baskın, S (Ed.), Recent Studies of Education in Various Occasions. Mauritius: Lambert Academic Publishing, 26-51.

7. Neyzi O, Bundak R, Gökçay G, et al. Reference Values for Weight, Height, Head Circumference, and Body Mass Index in Turkish Children. J Clin Res Pediatr Endocrinol 2015;7:280-93.

8. Kyritsi EM, Kanaka-Gantenbein C. Autoimmune Thyroid Disease in Specific Genetic Syndromes in Childhood and Adolescence. Front Endocrinol (Lausanne). $2020 ; 11: 543$.

9. Zimmermann MB, Molinari L, Spehl M, et al. Toward a consensus on reference values for thyroid volume in iodine-replete schoolchildren: results of a workshop on inter-observer and inter-equipment variation in sonographic measurement of thyroid volume. Eur J Endocrinol. 2001;144:213-20.

10. Zimmermann MB, Hess SY, Molinari L, et al. New reference values for thyroid volume by ultrasound in iodine-sufficient schoolchildren: a World Health Organization/Nutrition for Health and Development lodine Deficiency Study Group Report. Am J Clin Nutr. 2004;79:231-7.

11. Çolak E, Özkan B, Genç S, Poalt B. Ultrasonographic determination of thyroid volume in infants and children from Aegean region of Turkey and comparison with national and international references. J Pediatr Endocrinol Metab. 2021;34:457-64.

12. Kayastha P, Paudel S, Ghimire RK. Ultrasound measurement of thyroid isthmus thickness in clinically euthyroid subjects. Nepalese Journal of Radiology 2018;8:26-9.

13. Seker S, Tas I. Determination of Thyroid Volume and Its Relation with Isthmus Thickness. Eur J Gen Med 2010;7:125-9.

14. Won HS, Han SH, Oh CS, Chung IH, Won HJ, Kim JH. Location and morphometry of the thyroid isthmus in adult Korean cadavers. Anat Sci Int 2013;88:212-6.

15. Sultana SZ, Khalil M, Khan MK, et al. Morphometry of isthmus of thyroid gland in Bangladeshi cadaver. Mymensingh Med J 2011;20:366-70. 